\title{
Modulation of energy and protein supplies in sequential feeding in laying hens
}

\author{
M. Traineau ${ }^{1,2 \dagger}$, I. Bouvarel ${ }^{3}$, C. Mulsant ${ }^{2}$, L. Roffidal ${ }^{2}$, C. Launay ${ }^{2}$ and P. Lescoat ${ }^{1,4}$ \\ ${ }^{1}$ INRA, URA (UR83), F-37380 Nouzilly, France; ${ }^{2}$ INZO, Service R\&D Pondeuses, Rue de I'Eglise, CS 90019, 02400 Chierry, France; ${ }^{3}$ ITAVI, F-37380 Nouzilly, France; \\ ${ }^{4}$ AgroParisTech, UMR1048 SADAPT 16 rue Claude Bernard, 75005 Paris, France
}

(Received 31 January 2014; Accepted 5 July 2014; First published online 5 September 2014)

\begin{abstract}
Sequential feeding (SF) consists of splitting energy (E) and protein/calcium (P) fractions temporally, improving the feed conversion ratio (FCR) of hens compared with a continuous distribution during the day. In a previous study, the $E$ fraction (with a low level of protein) was provided in the morning, whereas the $P$ fraction (with low level of energy) was given in the afternoon. However, there is no clear evidence that a requirement in energy or proteins is connected to these distribution sequences, whereas the requirement for calcium is known to be required in the afternoon. To evaluate the effects on performances of the modulation of energy and protein supplies in $S F$, five different sequential treatments were offered: EOPO/EOPO; $E+P+/ E-P-; E+P-/ E-P+$; $E O P+/ E O P$ - and $E+P O / E-P O$ where $E+$ represents a high energy level, $E O$ a moderate one and $E-$ a low one (with the same meaning for $P$ regarding protein supply). Afternoon fractions were provided with particulate calcium. A total of 168 Hendrix hens were housed in individual cages from 20 to 39 weeks of age in two environmentally contrasted rooms. Feed intake in the morning and afternoon fractions, egg production, egg weight, BW and weight of digestive organs were recorded. No diet effect was observed concerning feed intake, egg production and BW. These results suggested that hens are not able to fit their feed intake on energy or protein level of fractions within half-day duration, whereas at the day scale same protein and energy intakes were observed. Moreover, the time of nutrient distribution in feeding did not seem to have an impact on birds' performances. These studies have also demonstrated that, despite strong environmental pressure, the hens with SF had attenuated performance but continue to produce eggs.
\end{abstract}

Keywords: laying hens, sequential feeding, energy, protein, environmental conditions

\section{Implications}

Improving laying hen performance may be achieved by maximizing nutrient utilization from current feedstuff. Supply of various energy and protein levels in sequential feeding could reduce the amount of food ingested while maintaining an equivalent level of production. Knowledge of the specific needs in energy and protein during the day will allow optimizing daily intake. This study can increase the robustness of the system to make it usable on a field scale and to ensure the relevant nutrient supply sequence, although time of supply does not seem to be of strong impact, except for $\mathrm{Ca}$.

\section{Introduction}

Several studies on Sequential Feeding (SF) have yielded good results through a meaningful improvement of the feed

\footnotetext{
E-mail: maxime.traineau@gmail.com
}

conversion ratio $(F C R)$ while maintaining similar performances compared with hens fed classically with continuous diets. The morning fractions were rich in energy, whereas the afternoon ones were rich in proteins \&\&and calcium (Umar Faruk et al., 2010 and 2011; Traineau et al., 2013). However, in these SF studies, hens fed with fractions with higher energy content in the morning than in the afternoon ate the same quantity of energy than the hens fed with the control diet on a day scale. In the morning, lower feed intake might be because of the regulation on energy in the diet (Gunawardana et al., 2009; Perez-Bonilla et al., 2012). Increased apparent metabolizable energy content of the diet reduced feed intake to maintain an optimal level of energy ingested (Valkonen et al., 2008), supporting the assumption that feed intake depends on the level of energy in the diet at the day scale. In SF, even if the level of energy is high in the morning and low in the afternoon, hens seem to be able to regulate their feed intake to have a same quantity of energy intake compared with continuous diet. Moreover, reduced 
feed intake, while maintaining identical laying performance, induced significant improvement of FCR (Grobas et al., 1999; Valkonen et al., 2008). These results might support the improvement in FCR for hens fed sequentially with a highenergy fraction in the morning and a high protein one in the afternoon. However, it is difficult to demonstrate that hens need energy mostly in the morning and protein in the afternoon according to their specific requirements connected with the egg production cycle, whereas several studies have shown that hens express a specific appetite for calcium in the afternoon for eggshell formation (Mongin and Sauveur, 1974; Chah and Moran, 1985). In all studies on SF, calcium was provided in the afternoon fraction in coarse form of calcium carbonate (Traineau et al., 2013; Batonon et al., 2014). To improve SF system robustness and to implement it on a commercial scale, it has to be more flexible. Traineau et al. (2013) showed that the energy fraction could be formulated with wheat or corn or with a mix of these two cereals. These diets lead to intermediate results between whole wheat in SF and usual continuous diet. This substitution between these cereals gives more flexibility for diet formulation compared with previous studies on SF (Umar Faruk et al., 2010). Regarding nutrient supply, Penz and Jensen (1991) showed that a feeding timetable could be a solution when using low-protein diets in layer diets while maintaining similar laying performances. When hens were fed a 'high-protein' diet (16\% CP) from 0400 to $0800 \mathrm{~h}$ and from 1400 to $2000 \mathrm{~h}$, and a 'low-protein' diet (13\% CP) from 0800 to $1400 \mathrm{~h}$, no difference in performance compared with control hens (16\% CP) was observed. However, hens fed continuously the 'low-protein diet' (13\% CP) or fed the 'lowprotein' diet from 0400 to $0800 \mathrm{~h}$ and from 1400 to $2000 \mathrm{~h}$, and the 'high-protein' diet from 0800 to $1400 \mathrm{~h}$, laid lower egg weights than the control group. This study supported that a provision of protein at given times influences the performances and has strengthened the hypothesis that hens need more protein after oviposition to meet the protein requirements for the synthesis of the albumen even though secretion might not be fully related to protein synthesis. However, Keshavarz (1998) had a similar experimental design (positive control 16\% CP, negative control 13\% CP, and two sequential diets combining $13 \%$ and $16 \%$ CP fractions), and concluded that optimum performance may be expected as long as the daily protein intake is adequate and satisfies the daily needs of laying hens. Therefore, additional experiments are required to further investigate SF. In addition, laying hens' performances not only depend on feed intake but also on other environmental effects. The cage size had an important effect on the laying performances by reducing the laying rate (Cunningham et al., 1988), and small cages induce more cracked and dirty eggs (Abrahamsson and Tauson, 1997). In addition, apparition of parasites in the rearing room could decrease the hens' performances. Red mites' pressure leads to decrease in feed consumption and reduce eggs' quality and production (Lesna et al., 2009).

The first aim of this study was, by modulating the energy and protein fractions and nutritional contents in SF for laying hens, to determine their impacts on intake, growth and production of hens because of the sequential supply of nutrients. The second aim was to define whether the ranking of the diet was the same event if hens are reared in different conditions. This study should therefore help to determine the nutritional needs of the hens at different times of the day.

\section{Material and methods}

\section{Birds and housing}

A total of 140 Hendrix layer hens were housed in 2 two-tier batteries having individual cages equipped with a nipple drinker. For the duration of the experiment, the temperature was maintained in both rooms between $18^{\circ} \mathrm{C}$ and $22^{\circ} \mathrm{C}$. All hens had individual feeders and have been randomly assigned in battery cages. The birds were habituated to SF with a mix of whole wheat and a balancer from weeks 16 to 18. The photoperiod was $12 \mathrm{~L}: 12 \mathrm{D}$ at week 16 and reached $16 \mathrm{~L}: 8 \mathrm{D}$ at week 18 and remained at this level until the end of experiment. Lights were on at week 16 from 0500 to $1700 \mathrm{~h}$ and from 0400 to $2000 \mathrm{~h}$ from weeks 18 to 39 .

The experimental period ran from weeks 19 to 39. Birds were housed in two rooms within the same building and kept in individual cages from weeks 16 to 39. Birds were divided into five groups of 12 birds in the first room, and into five groups of 16 birds in the second room. The difference between the two rooms was mainly related to the size of the cages: in the first room cages were $45 \mathrm{~cm}$ width $\times 62 \mathrm{~cm}$ depth $\times 80 \mathrm{~cm}$ height, and in the second room $25 \mathrm{~cm}$ width $\times 48 \mathrm{~cm}$ depth $\times 48 \mathrm{~cm}$ height. Moreover, the second room had an environmental pressure because of red mites. This room was progressively infected with red mites for the duration of the experimental period, which altered whole performance of hens, despite treatments against mites.

\section{Experimental treatments}

Diets fed during the experimental period are described in Table 1. Dietary contents of previous experiments on SF in our lab were based on the utilization of two different cereals in the morning fraction (wheat and maize; Traineau et al., 2013); nevertheless, the present study is focused on the nutritional values of the offered diets in SF. Diets were distributed sequentially. Birds were offered $62.5 \mathrm{~g}$ in the morning and beginning of the afternoon (0830 to $1530 \mathrm{~h})$, and $62.5 \mathrm{~g}$ in the late afternoon and early morning (1530 to $0800 \mathrm{~h}$ and 0400 to $0830 \mathrm{~h}$ ), $125 \mathrm{~g} /$ day being $105 \%$ of the recommended diet supply. For all diets, calcium is provided in coarse form, in the fraction distributed in the afternoon. No diet was formulated with a low-energy level $(E-)$ in the morning fraction. This fraction was systematically less consumed than the afternoon one for every previous study, inducing overall shortage in ME intake. To modulate the daily intakes' dynamic of energy and protein, five sequential diets were offered: EOP0/EOPO (2601 kcal/kg; 16.5 CP/2601 $\mathrm{kcal} / \mathrm{kg} ; 16.5 \mathrm{CP}) ; \mathrm{E}+\mathrm{P}+/ \mathrm{E}-\mathrm{P}-(2901 \mathrm{kcal} / \mathrm{kg} ; 19.5 \mathrm{CP}$; $2303 \mathrm{kal} / \mathrm{kg} ; 13.5 \mathrm{CP}) ; \mathrm{E}+\mathrm{P}-/ \mathrm{E}-\mathrm{P}+(2905 \mathrm{kcal} / \mathrm{kg} ; 13.5$ 
Table 1 Composition of experimental diets given to laying hens between 19 and 39 weeks of age with a combination of $62.5 \mathrm{~g}$ of morning fraction between 0830 and $1530 \mathrm{~h}$ and $62.5 \mathrm{~g}$ of afternoon fraction between 1530 and $0830 \mathrm{~h}$ (no light between 2000 and $0400 \mathrm{~h}$ )

\begin{tabular}{|c|c|c|c|c|c|c|c|c|c|c|}
\hline & \multicolumn{2}{|c|}{ EOPO/EOPO } & \multicolumn{2}{|c|}{$E+P+/ E-P-$} & \multicolumn{2}{|c|}{$E+P-/ E-P+$} & \multicolumn{2}{|c|}{$\mathrm{EOP}+/ \mathrm{EOP}-$} & \multicolumn{2}{|c|}{$E+P 0 / E-P 0$} \\
\hline & $\begin{array}{l}\text { EOPO } \\
\text { morning }\end{array}$ & $\begin{array}{l}\text { EOPO Ca + } \\
\text { afternoon }\end{array}$ & $\begin{array}{l}\mathrm{E}+\mathrm{P}+ \\
\text { morning }\end{array}$ & $\begin{array}{c}\mathrm{E}-\mathrm{P}-\mathrm{Ca}+ \\
\text { afternoon }\end{array}$ & $\begin{array}{l}\mathrm{E}+\mathrm{P}- \\
\text { morning }\end{array}$ & $\begin{array}{l}\mathrm{E}-\mathrm{P}+\mathrm{Ca}+ \\
\text { afternoon }\end{array}$ & $\begin{array}{l}\text { EOP + } \\
\text { morning }\end{array}$ & $\begin{array}{l}\mathrm{EOP}-\mathrm{Ca}+ \\
\text { afternoon }\end{array}$ & $\begin{array}{l}\mathrm{E}+\mathrm{PO} \\
\text { morning }\end{array}$ & $\begin{array}{c}\mathrm{E}-\mathrm{P} 0 \mathrm{Ca}+ \\
\text { afternoon }\end{array}$ \\
\hline \multicolumn{11}{|l|}{ Ingredient (\%) } \\
\hline Corn & 31.1 & 30 & 33 & 28 & 39.7 & 23.2 & 27 & 33.1 & 38 & 25 \\
\hline Wheat & 30 & 29 & 34.6 & 28.7 & 39 & 22 & 27.9 & 33 & 36.3 & 26 \\
\hline Soybean meal & 9.5 & 17 & 17 & 4 & 6 & 19 & 16.5 & 13.5 & 13 & 11 \\
\hline Rapeseed meal & 5 & & 5 & 5 & 5 & 5 & 5 & & 5 & 5 \\
\hline Sunflower meal & 10 & & 3.7 & 10 & 0.3 & 9.1 & 10 & & 4.8 & 10 \\
\hline Wheat bran & 10 & & & 4.5 & 7 & & 10 & & & 2 \\
\hline Calcium carbonate & 1.57 & 15.36 & & 15.35 & & 15.24 & & 15.38 & & 15.3 \\
\hline Corn gluten & & 4.8 & 3.7 & 1.4 & & 3.4 & 0.8 & 1.3 & 0.2 & 2.7 \\
\hline Dicalcium phosphate & 1.01 & 1.34 & 1.15 & 1.19 & 1.1 & 1.23 & 0.97 & 1.35 & 1.17 & 1.21 \\
\hline Soybean oil & 0.5 & 1.2 & 0.5 & 0.5 & 0.5 & 0.5 & 0.5 & 1.1 & 0.5 & 0.5 \\
\hline Premix ${ }^{1}$ & 1 & 1 & 1 & 1 & 1 & 1 & 1 & 1 & 1 & 1 \\
\hline DL-methionine & 0.17 & 0.17 & 0.20 & 0.12 & 0.15 & 0.21 & 0.22 & 0.15 & 0.18 & 0.16 \\
\hline L-lysine & 0.19 & 0.15 & 0.16 & 0.22 & 0.20 & 0.11 & 0.14 & 0.12 & 0.14 & 0.18 \\
\hline L-tryptophane & & 0.01 & & & & & & & & \\
\hline L-threonine & & & & 0.005 & 0.02 & & & & & \\
\hline \multicolumn{11}{|l|}{ Nutritional values ${ }^{2}$} \\
\hline $\begin{array}{l}\text { ME calculated } \\
(\mathrm{kcal} / \mathrm{kg})\end{array}$ & 2601 & 2600 & 2901 & 2303 & 2905 & 2302 & 2599 & 2597 & 2903 & 2302 \\
\hline CP calculated $(\mathrm{g} / \mathrm{kg})$ & 16.5 & 16.6 & 19.5 & 13.5 & 13.5 & 19.4 & 19.6 & 13.6 & 16.4 & 16.5 \\
\hline Lysine dig. (\%) & 0.72 & 0.72 & 0.85 & 0.59 & 0.59 & 0.85 & 0.86 & 0.60 & 0.71 & 0.72 \\
\hline Methionine dig. (\%) & 0.42 & 0.42 & 0.49 & 0.34 & 0.34 & 0.51 & 0.50 & 0.34 & 0.42 & 0.42 \\
\hline Threonine dig. (\%) & 0.51 & 0.53 & 0.62 & 0.418 & 0.42 & 0.64 & 0.62 & 0.42 & 0.52 & 0.53 \\
\hline Tryptophan dig. (\%) & 0.17 & 0.16 & 0.19 & 0.13 & 0.13 & 0.19 & 0.20 & 0.13 & 0.16 & 0.16 \\
\hline Calcium (\%) & 1.2 & 6.6 & 0.6 & 6.6 & 0.5 & 6.6 & 0.6 & 6.6 & 0.6 & 6.6 \\
\hline Total P (\%) & 0.65 & 0.52 & 0.59 & 0.59 & 0.56 & 0.62 & 0.67 & 0.50 & 0.59 & 0.60 \\
\hline Available P (\%) & 0.32 & 0.32 & 0.32 & 0.32 & 0.32 & 0.32 & 0.32 & 0.32 & 0.32 & 0.32 \\
\hline $\begin{array}{l}\text { Coarse particles } \\
>2.5 \mathrm{~mm}\end{array}$ & 19.3 & 26.3 & 31 & 16.5 & 29 & 21.6 & 22.2 & 22.5 & 28.3 & 22 \\
\hline $\begin{array}{l}\text { Fine } \\
\text { particles }<1.18 \mathrm{~mm}\end{array}$ & 48.7 & 28.9 & 28.5 & 52.6 & 31.2 & 44 & 37.9 & 32.2 & 26.7 & 35.2 \\
\hline
\end{tabular}


CP/2302 kcal/kg; 19.6 CP); EOP + /EOP - (2599 kcal/kg; 19.6 $\mathrm{CP} / 2597 \mathrm{kcal} / \mathrm{kg} ; 13.6 \mathrm{CP}$ ) and E + P0/E - P0 (2903 kcal/kg; $16.4 \mathrm{CP} / 2302 \mathrm{kcal} / \mathrm{kg} ; 16.5 \mathrm{CP}$ ). Diets were formulated according to INRA recommendations, and proposed nutritional contents were based on the hypothesis of 50/50 intakes of the morning and afternoon fractions (Sauvant et al., 2004). Water was given ad libitum throughout the experimental period.

\section{Measurements}

Particle size profile was measured. Four different sieves were used to characterize the particle size $(2.5,1.6,1.18$ and $>1.18 \mathrm{~mm}$ ). Feed intake was individually recorded every week for the morning and afternoon fractions. Egg production was recorded on a daily basis. Egg weight was recorded twice a week by weighing all eggs produced on the measuring day. Weights of egg components (yolk, albumen and shell) were determined on the daily samples every 4 weeks, starting at week 22 . Shells were washed and dried for $12 \mathrm{~h}$ in a drying oven at $70^{\circ} \mathrm{C}$ and then weighed.

BW was recorded at 16, 19,23,27, 31, 35 and 39 weeks of age. Body composition was predicted with a noninvasive method based on bioelectrical impedance analysis at 19, 27 and 35 weeks of age. The technique has been developed by the company INZO ${ }^{\circ 1}$ and predicts the body composition by an instrument of impedance, which was calibrated through the chemical analysis of birds. Impedance measurements of resistance (Rs) and reactance (Xc) are taken using two electrodes placed on the animal's legs and distributing a very low-intensity current. It is assumed that the electrical impedance of the biological organism is indicative of the highly conductive fat-free component (Berg and Marchello, 1994). The electrical impedance of a tissue depends on its fluid and electrolyte content (Rutter et al., 1998) and therefore on the electrical properties of different tissues in connection with their relative proportions of muscle, lipid, water and ash. For the duration of a full day, in week 27, feed intake kinetics of hens was measured in the second room. Every hour, the feeders were weighed to set the amount of food ingested by the hens during this period. This operation was performed for the two fractions (morning and afternoon) throughout the light period from 0400 to $2000 \mathrm{~h}$. Metabolizable energy (ME; $\mathrm{kcal} / \mathrm{bird}$ per day) and protein (g/bird per day) intake were calculated as a product of feed intake and ME and protein contents of the experimental diets, respectively.

At the end of the trial, 10 birds per treatment in the second room were randomly selected, weighed and injected with $\mathrm{Na}$ pentobarbital solution $(1 \mathrm{ml} / \mathrm{kg}$ ) for killing birds without pain. The weight of the digestive organs was recorded to assess the effect of feeding system on these organs. The abdominal cavity was opened and the digestive tract dissected and separated into the gizzard, small intestine, pancreas and liver. The small intestine was separated into the duodenum, jejunum and ileum. Each segment was first emptied before weighing. The gizzard was placed into an iced container

\footnotetext{
${ }^{1}$ INZO ${ }^{\circ}$ SAS rue de I'Eglise-BP 5001902407 Chierry Cedex.
}

$\left(-4^{\circ} \mathrm{C}\right)$ for $24 \mathrm{~h}$ to facilitate the removal of the surrounding fat before being emptied and weighed.

For the evaluation of the apparent digestibility of the hens, Titanium dioxide was added at a rate of $5 \mathrm{~g} / \mathrm{kg}$ as a dietary marker in the two fractions. Chemical analyses were performed for $\mathrm{TiO}_{2}$ concentrations in each fraction of the diet and in the feces. Analysis of $\mathrm{TiO}_{2}$ was performed by colorimetric method. In the presence of sulfuric acid, $\mathrm{TiO}_{2}$ and $\mathrm{H}_{2} \mathrm{O}_{2}$ cause a yellow coloration read by absorbance at $410 \mathrm{~nm}$ (TECAN, Infinite200, Grödig, Austria). This method was developed by Short et al. (1996). Apparent digestibility was calculated as follows:

$$
\begin{aligned}
\mathrm{TTAR}= & 1-\left[\left(\text { Nutrient }_{\text {feces }} / \text { Nutrient }_{\text {diet }}\right) \times\left(\mathrm{TiO}_{2 \text { diet }} / \mathrm{TiO}_{2 \text { feces }}\right)\right] \\
& \times 100
\end{aligned}
$$

where TTAR is total tract apparent retention, Nutrient $t_{\text {feces }}$ and $\mathrm{TiO}_{2 \text { feces }}$ are the concentrations of dietary components and of $\mathrm{TiO}_{2}$ in the excreta, Nutrient ${ }_{\text {diet }}$ and $\mathrm{TiO}_{2 \text { diet }}$ represent the concentrations of the same dietary components and the $\mathrm{TiO}_{2}$ in the feeds. Concentrations in the sequential diets were obtained by combining the actual quantities of ingested morning and afternoon fractions with their respective content of nutrient and titanium dioxide. At 32 weeks of age, blood sampling in the wing vein was used to define the level of hematocrit as an indicator of the effect of red mites on the health of the hens.

\section{Statistical analysis}

Data collected during the experiment were analyzed based on two different periods: during the increase of lay (from weeks 20 to 26) and after the peak (from weeks 27 to 39). Averaged values from each period were analyzed using StatView (version 5, SAS Institute Inc., Cary, NC, USA). A two-way ANOVA was used to test treatment and room effect on all measured parameters. If the ANOVA was significant $\left(P<0.01:{ }^{*}, P<0.05:{ }^{*}, P<0.1\right.$ : obtained $P$-value, $P>0.1$ : ns), a post hoc Bonferroni test was used, differences between diets on the same line are illustrated with different letters $(a$, $\mathrm{b}, \ldots)$ if $P<0.05$, and with capital letters $(A, B, \ldots)$ if $P<0.1$.

\section{Results}

\section{Diet and room effect on egg production, BW, body composition and FCR}

Weeks 20 to 26. (Table 2) No difference owing to the diet was observed for the laying performances (egg weight, egg production and egg mass) and for the FCR. No difference was observed for initial BW and body composition at week 19. BW gain (BWG; weeks 20 to 27) was significantly affected by the diets $(P=0.02)$. Hens with $E+P+/ E-P-$ had lower gain than $E+P-/ E-P+$. There was a difference between the two rooms for the egg mass $(P=0.01)$ and a tendency for egg production $(P=0.06)$. An interaction between the diet and room was observed $(P=0.04)$. Hens consuming EOPO/EOPO in the second room having higher BWG $(78.2 \mathrm{~g})$ than those in the first room $(60.2 \mathrm{~g})$, whereas for all other 
Table 2 Effects on egg production, FCR, BW and body composition of laying hens from 20 to 39 weeks old offered a combination of $62.5 \mathrm{~g}$ of morning fraction between 0830 and $1530 \mathrm{~h}$ and $62.5 \mathrm{~g}$ of afternoon fraction between 1530 and $0830 \mathrm{~h}$ (no light between 2000 and $0400 \mathrm{~h}$ )

\begin{tabular}{|c|c|c|c|c|c|c|c|c|c|c|c|}
\hline & EOPO/EOPO & $E+P+/ E-P-$ & $E+P-/ E-P+$ & $\mathrm{EOP}+/ \mathrm{EOP}-$ & $E+P 0 / E-P 0$ & Room 1 & Room 2 & s.e.m. & $\operatorname{Diet}^{1}$ & Room $^{1}$ & Diet $\times$ room $^{1}$ \\
\hline \multicolumn{12}{|l|}{ Weeks 20 to 26} \\
\hline Egg production (\%) & 82.4 & 86 & 80.7 & 79.3 & 82.8 & 84.9 & 80.3 & 1.2 & ns & 0.06 & ns \\
\hline Egg weight (g) & 53.4 & 50.9 & 51 & 53.7 & 53.8 & 52.6 & 52.6 & 0.7 & ns & ns & ns \\
\hline Egg mass ( $g /$ hen per day) & 43.1 & 43.8 & 41.1 & 41.9 & 43.8 & 44.3 & 41.6 & 0.6 & ns & * & ns \\
\hline FCR & 2.42 & 2.36 & 2.54 & 2.68 & 2.42 & 2.45 & 2.51 & 0.05 & ns & ns & ns \\
\hline Initial BW week 19 (g) & 1421 & 1419 & 1394 & 1427 & 1412 & 1424 & 1408 & 8 & ns & ns & ns \\
\hline BW gain $(g)$ & $272 a b$ & $216 a$ & $283 b$ & $260 a b$ & $273 a b$ & 282 & 245 & 7 & * & ** & * \\
\hline Body composition: \% fat week 19 & 11.4 & 11.3 & 11 & 11.6 & 11.2 & 11.3 & 11.4 & 1.4 & ns & ns & ns \\
\hline Body composition: \% protein week 19 & 18.3 & 18.3 & 18.3 & 18.2 & 18.3 & 18.3 & 18.2 & 0.3 & ns & ns & ns \\
\hline \multicolumn{12}{|l|}{ Weeks 27 to 39} \\
\hline Egg production (\%) & 98.1 & 96.8 & 98.1 & 95.9 & 95.4 & 98.3 & 95.8 & 0.3 & ns & *** & ns \\
\hline Egg weight $(\mathrm{g})$ & 58 & 57 & 57.7 & 58.6 & 58.9 & 59.3 & 57.2 & 0.3 & ns & $* * *$ & ns \\
\hline Egg mass (g/hen per day) & 56.9 & 55.2 & $56.7 \mathrm{a}$ & 56.2 & 56.2 & 58.2 & 54.8 & 0.4 & ns & $* * *$ & ns \\
\hline FCR & 2.04 & 2.11 & 2.07 & 2.07 & 2.06 & 2.03 & 2.09 & 0.03 & ns & ** & ns \\
\hline BW week 27 (g) & 1692 & 1635 & 1677 & 1687 & 1685 & 1706 & 1653 & 9 & ns & ** & ns \\
\hline Final BW week 39 (g) & 1760 & 1699 & 1761 & 1733 & 1695 & 1787 & 1686 & 12 & ns & ** & ns \\
\hline BW gain $(g)$ & $68 \mathrm{~b}$ & 64 & $81 a$ & 45 & $9 b$ & 81 & 32 & 8 & * & $* * *$ & ns \\
\hline Body composition: \% fat week 27 & 16.1 & 15.2 & 16 & 16 & 16.1 & 16.3 & 15.6 & 0.2 & ns & * & ns \\
\hline Body composition: \% protein week 27 & 17.3 & 17.4 & 17.3 & 17.3 & 17.3 & 17.3 & 17.3 & 0.3 & ns & ns & ns \\
\hline Body composition: \% fat week 35 & 16.8 & 16.5 & 16.6 & 16.9 & 16.4 & 17.6 & 15.9 & 0.2 & ns & $* * *$ & ns \\
\hline Body composition: \% protein week 35 & 17 & 17 & 17.1 & 17 & 17.1 & 16.9 & 17.2 & 0.4 & ns & $* * *$ & ns \\
\hline
\end{tabular}

FCR = feed conversion ratio (feed intake/egg mass).

Fractions were a combination of energy (E) and protein (P) levels, with low $(-)$, medium $(0)$ or high $(+)$ values. $P>0.05$; values within a row with common letters $(a$, b) differ significantly using Bonferroni-Dunnet test at $5 \%$

significance level.

${ }^{* *} P<0.01 ;{ }^{*} P<0.05$ 
birds hens in the second room had lower BWG than those of the first one.

Weeks 27 to 39. Egg production, egg weight, egg mass, BW (weeks 27 and 39), BWG and FCR were reduced for hens in the second room compared with hens in the first one. No diet effect was observed on egg performance (egg production, egg weight and egg mass), FCR and BW at 39 weeks of age. The only significant difference is for hens with $\mathrm{E}+\mathrm{PO} / \mathrm{E}-\mathrm{PO}$, which had lower BWG than hens with $E+P-/ E-P+$ (no difference with the other diets). There was no interaction between room and diet for all measured parameters. There was neither a diet nor room effect for the egg components. For body proportion in protein and fat, an effect of age was observed. There was no diet effect on fat and protein compositions on weeks 19,27 and 35 .

After hens' slaughtering at 39 weeks of age, the main digestive organs and abdominal fat were weighed. However, there were no significant differences between diets on any tested values (data not shown). There was no diet effect on the apparent digestibility. The values of apparent digestibility performed on sequentially fed hens were similar to values usually obtained on continuously fed hens, as observed in previous studies with similar bred hens. Hematocrit on week 32 underlined a difference between the two rooms: $30.5 \%$ in the first room compared with $25.4 \%$ in the second one.

\section{Diet and room effects on feed intake, ME intake and CP intake}

Weeks 20 to 26. (Table 3) All parameters were degraded in the second room. There was no diet effect on total and afternoon feed intakes. However, diet affected morning feed intakes (with a tendency for lower level for EOP + /EOP - and EOPO/EOPO compared with $E+P-/ E-P+$ ). Diets did not affect total ME intake, but hens had different ME intake level during the day. For the morning ME intake, all birds with high energy in the morning $(E+P+/ E-P-, E+P-/ E-$ $P+$ and $E+P 0 / E-P O)$ ate more energy compared with birds with lower levels on energy in the morning (EOP + /EOP and $\mathrm{EOPO/EOPO).} \mathrm{Concerning} \mathrm{the} \mathrm{afternoon} \mathrm{ME} \mathrm{intake,} \mathrm{hens}$ with an $\mathrm{E}$ - fraction in the afternoon ate less energy than hens with the two other diets $(E O P+/ E O P$ - and EOPO/ EOPO). For total CP intake, no diet effects were observed, but diets affected the $\mathrm{CP}$ intake during the day. For the morning $C P$ intake, three different groups were observed. Hens with $\mathrm{P}+$ in the fraction of the morning $(\mathrm{E}+\mathrm{P}+/ \mathrm{E}-\mathrm{P}-$ and $E O P+/ E O P-)$ had the highest level of $C P$ intake, hens with $\mathrm{PO}$ in these fractions in the morning (EOPO/EOPO and $\mathrm{E}+\mathrm{PO} /$ $E-P 0)$ had an intermediate level of $C P$ intake and hens with $P$ - in the morning $(E+P-/ E-P+)$ had the lowest level of CP intake.

Weeks 27 to 39. All parameters were degraded in the second room. There was no diet effect on feed intakes and total ME intake. For ME intake in the morning, all hens with high energy in the morning $(E+P+/ E-P-, E+P-/ E-P+$ and $\mathrm{E}+\mathrm{PO} / \mathrm{E}-\mathrm{PO}$ ) ate more energy compared with birds with lower level on energy in the morning (EOP + /EOP - and EOPO/EOP0). For the afternoon ME intake, all birds with an $E$ - fraction in the afternoon $(E+P+/ E-P-, E+P-/$ $E-P+$ and $E+P 0 / E-P 0)$ ate less energy than hens with the two other diets (EOP +/EOP - and EOPO/EOPO). Concerning total $\mathrm{CP}$ intake, there was no difference between all diets. For the morning $C P$ intake, three different levels were observed: a high level of protein intake for $E+P+/ E-P-$, $\mathrm{EOP}+/ \mathrm{EOP}-$ and EOPO/EOPO, an intermediate level for $E+P O / E-P 0$ and the lowest level for $E+P-/ E-P+$. For $C P$ afternoon intake, three levels were still reported: the highest for $\mathrm{E}+\mathrm{P}-/ \mathrm{E}-\mathrm{P}+$, an intermediate one for $\mathrm{E}+\mathrm{P} 0 /$ $E-P O$ and a low level for $E+P+/ E-P-, E O P O / E O P O$ and $\mathrm{EOP}+/ \mathrm{EOP}-$. Concerning feed intake dynamics (Figure 1), there was no diet effect on the eating rate. However, this figure allows us to highlight the daily shape of ingestion induced by SF: feed intake was induced by the diet distribution, and hens were expecting the next diet because of the learning of the timetable of the feed supply.

\section{Discussion}

The main objective of this work was to study the influence of different kinetics of nutrient supply in SF on performances of laying hens. Only sequential diets were given. One treatment brought EOPO in the morning and EOPO with $\mathrm{Ca}$ in the afternoon, which may mimic a continuous diet regarding energy and protein supply. However, the two fractions were contrasted in their raw materials content and their particle size. These differences might explain that for the 20- to 26week period, hens with EOPO in the morning (19\% of large particles and $49 \%$ fines) consumed less than hens that had EOPO + Ca at the same time (29\% of large particles and $31 \%$ fine). Indeed, coarse particle induces an increase in intake compared with higher percentage of fine particles diet (Nir et al., 1990; Safaa et al., 2009). For the first room, with a low environmental pressure, rate of lay and egg mass were similar to those observed in SF in previous studies (Umar Faruk et al., 2010; Traineau et al., 2013). However, FCR (+5.1\%) and egg weight $(-5.3 \%)$ were different from those observed by Traineau et al., (2013), which may be because of a difference in total protein intake $17.5 \mathrm{~g} /$ day in our trial compared with $19.0 \mathrm{~g} /$ day for Traineau et al. (2013). Summers and Leeson (1985) showed that egg size could be altered by $1.3 \mathrm{~g}$ when the protein intake varied between 17 and $18.9 \mathrm{~g}$.

For the duration of the experiment, environmental pressure increased in the second room. From weeks 20 to 26, feed intake levels were lower in the second room compared with the first one, whereas egg weight, weight gain and FCR were not affected. From weeks 27 to 39, difference between the two rooms strongly increased. Red mites' pressure can lead to decreases in feed consumption and reduce eggs' quality and production (Chauve, 1998; Lesna et al., 2009). To implement the evidence of the negative effect of these red mites, measure of hematocrit on week 32 showed a strong difference between the two rooms $(30.5 \%$ in the first room compared with $25.4 \%$ in the second one). However, the 
Table 3 Effects on feed, ME and CP intakes of laying hens from 20 to 39 weeks old offered a combination of $62.5 \mathrm{~g}$ of morning fraction between 0830 and $1530 \mathrm{~h}$ and $62.5 \mathrm{~g}$ of afternoon fraction between 1530 and $0830 h$ (no light between 2000 and 0400 h)

\begin{tabular}{|c|c|c|c|c|c|c|c|c|c|c|c|}
\hline & EOPO/EOPO & $E+P+/ E-P-$ & $E+P-/ E-P+$ & $\mathrm{EOP}+/ \mathrm{EOP}-$ & $E+P 0 / E-P 0$ & Room 1 & Room 2 & s.e.m. & $\operatorname{Diet}^{1}$ & Room $^{1}$ & Diet $\times$ room $^{1}$ \\
\hline \multicolumn{12}{|l|}{ Weeks 20 to 26} \\
\hline Total feed intake (g/bird per day) & 102.8 & 102.3 & 103 & 103.1 & 104.9 & 106 & 101.1 & 0.8 & ns & ** & ns \\
\hline Morning & $48.3 b$ & 49.5ab & $52 a$ & $47.7 b$ & $50.7 a b$ & 50.8 & 48.8 & 0.4 & ** & ** & ns \\
\hline Afternoon & 54.5 & 52.8 & 51 & 55.4 & 54.2 & 55.2 & 52.4 & 0.5 & ns & ** & ns \\
\hline Total ME intake (kcal/bird per day) & 267 & 265 & 268 & 268 & 272 & 275 & 263 & 2 & ns & ** & ns \\
\hline Morning & $126 b$ & $143 a$ & $151 a$ & $124 b$ & $147 a$ & 142 & 136 & 2 & $* * *$ & ** & ns \\
\hline Afternoon & $141 b$ & $122 a$ & $117 a$ & $144 b$ & $125 a$ & 134 & 127 & 2 & * & ** & ns \\
\hline Total CP intake (g/bird per day) & 17 & 16.7 & 16.9 & 16.9 & 17.2 & 17.4 & 16.6 & 0.1 & ns & ** & ns \\
\hline Morning & $7.9 \mathrm{c}$ & $9.6 a$ & $7 \mathrm{~b}$ & $9.3 \mathrm{a}$ & $8.3 \mathrm{c}$ & 8.6 & 8.3 & 0.1 & $* * *$ & * & ns \\
\hline Afternoon & $9.1 \mathrm{c}$ & $7.1 \mathrm{a}$ & $9.9 \mathrm{~b}$ & $7.6 a$ & $8.9 c$ & 8.8 & 8.3 & 0.1 & $* * *$ & ** & ns \\
\hline \multicolumn{12}{|l|}{ Weeks 27 to 39} \\
\hline Total feed intake (g/bird per day) & 115.7 & 116.1 & 116.8 & 115.8 & 115.4 & 118.2 & 114.3 & 0.6 & ns & ** & ns \\
\hline Morning & 53.4 & 53.8 & 54.5 & 51.8 & 53.6 & 54 & 53 & 0.4 & ns & ns & * \\
\hline Afternoon & 62.3 & 62.3 & 62.3 & 64 & 61.8 & 64.2 & 61.3 & 0.4 & ns & $* * *$ & ns \\
\hline Total ME intake (kcal/bird per day) & 301 & 300 & 302 & 301 & 298 & 306 & 296 & 2 & ns & ** & ns \\
\hline Morning & $139 b$ & $156 a$ & $156 a$ & $135 b$ & $156 a$ & 150 & 147 & 1 & $* * *$ & 0.06 & * \\
\hline Afternoon & $162 b$ & $144 a$ & $146 a$ & $166 \mathrm{~b}$ & $142 a$ & 156 & 149 & 1 & ** & $* * *$ & ns \\
\hline Total CP intake (g/bird per day) & 19.1 & 18.9 & 19.4 & 18.8 & 19 & 19.4 & 18.8 & 0.1 & ns & ** & ns \\
\hline Morning & $10.8 a$ & $10.5 a$ & $7.3 \mathrm{~b}$ & $10.1 \mathrm{a}$ & $8.8 \mathrm{c}$ & 9.2 & 9 & 0.1 & $* * *$ & ns & 0.06 \\
\hline Afternoon & $8.3 a$ & $8.4 a$ & $12.1 \mathrm{~b}$ & $8.7 a$ & $10.2 \mathrm{c}$ & 10.2 & 9.8 & 0.1 & $* * *$ & $* *$ & ns \\
\hline
\end{tabular}

Fractions were a combination of energy $(\mathrm{E})$ and protein $(\mathrm{P})$ levels, with low $(-)$, medium $(0)$ or high $(+)$ values.

Fractions were a combination of energy $(E)$ and protein $(P)$ levels, with low $(-)$, medium $(0)$ or high $(+)$ values.
$P>0.05$; values within a row with common letters $(a, b, c)$ differ significantly using Bonferroni-Dunnet test at $5 \%$ significance level.
$1 * * P<0.01:{ }^{*} P<0.05$. 
Traineau, Bouvarel, Mulsant, Roffidal, Launay and Lescoat

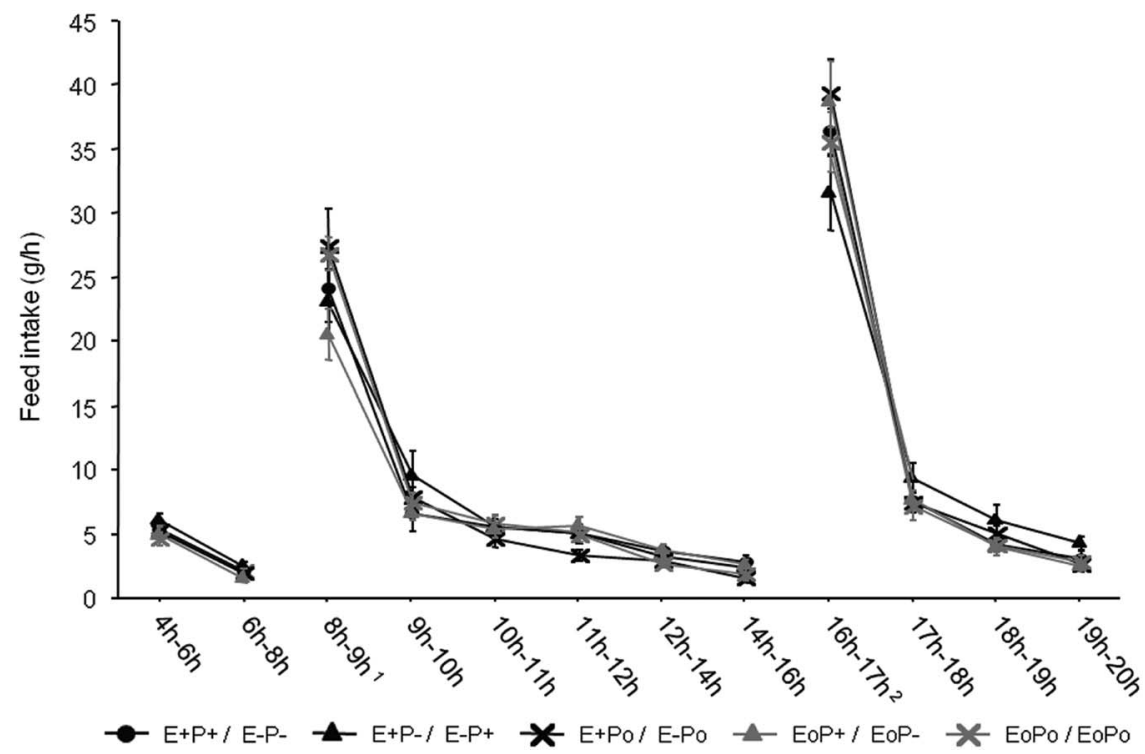

Figure 1 Effects of different diets on feed intake $(\mathrm{g} / \mathrm{h}$ ) during a whole day at 27 weeks old for laying hens fed between 19 and 39 weeks of age, with a combination of $62.5 \mathrm{~g}$ of morning fraction between 0830 and $1530 \mathrm{~h}$ and $62.5 \mathrm{~g}$ of afternoon fraction between 1530 and $0830 \mathrm{~h}$ (no light between 2000 and $0400 \mathrm{~h}$ ). ${ }^{1}$ Morning distribution; ${ }^{2}$ afternoon distribution.

ranking between the diets was similar in the two rooms, indicating that sequential diets were impacted in the same order of magnitude regardless of their contents.

The main question was to determine the impact of nutrient distribution on hens' responses. First of all, regardless of the protein or energy timetable supply, a higher intake was observed for the afternoon fraction compared with the morning one as obtained by Umar Faruk et al. (2010) and Traineau et al. (2013). Despite contrasted energy and protein supply timetables, hens were not affected on the quantity of feed intake. The morning and afternoon fractions differed on the energy and protein level between all diets. However, hens did not seem to be able to fit their intake level on the diets' composition. Some authors showed that hens are not able to fit their feed intake on CP level in the diet (Summers and Leeson, 1985). These results are in accordance with our observation on the nonregulation of feed intake on protein content of the diet. On the contrary, regarding the effect of the energy level, hens seem to be able to regulate their feed intake on ME level of the diet (Plavnik et al., 1997; Nahashon et al., 2005). Bouvarel et al. (2010) showed that hens reduced their feed intake with the increase in energy content in the diet. In our studies, hens did not seem to be able to adjust their consumption on the energy density of the offered fraction. However, energy and protein intakes' dynamics are different during the day between diet, keeping in mind that the afternoon fraction was not energy rich (no $E+$ ).

The absence of differences with contrasted fractions does not allow to define clearly the nutritional needs in the different time of day in SF. It might be proposed that if hens were offered enough nutrients in the day, their sequence did not seem to have a strong impact on the birds' performances. In this study, as hens received in the morning a fraction rich in energy (or an average level), it might suggest that in $\mathrm{SF}$, it would be better to bring the fraction rich in energy in the morning to get satisfactory results. A low level in the energy fraction in the morning may not be possible because of the low level of feed intake of this fraction, which is constantly observed during all work in SF. These studies have also demonstrated that, despite significant health pressure, hens fed sequentially are able to produce eggs and ensure a normal growth.

\section{Acknowledgements}

The authors thank Philippe Didier and Michel Couty (INRA) for their technical assistance. They are grateful to the experimental unit (UE PEAT) for its help in the set up of the experiment. Scientific and financial support of INZO ${ }^{\circ}$ (France) was highly appreciated. Barbara Konsak was thanked for the English corrections.

\section{References}

Abrahamsson P and Tauson R 1997. Effects of group size on performance, health and birds' use of facilities in furnished cages for laying hens. Acta Agriculture Scandinavica 47, 254-260.

Batonon DI, Traineau M, Bouvarel I, Roffidal L and Lescoat P 2014. Capacity of laying hens in sequential feeding to adjust their feed consumption when offered previously a nutritionally unbalanced diet. Archiv fur Geflugelkunde 78, 1612-1628.

Berg EP and Marchello MJ 1994. Bioelectrical-impedance analysis for the prediction of fat-free mass in lambs and lamb carcasses. Journal of Animal Science 72, 322-329.

Bouvarel I, Nys Y, Panheleux M and Lescoat P 2010. How hen's diet influences eggs quality? INRA Production Animal 23, 167-182.

Chah CC and Moran ET 1985. Egg characteristics of high-performance hens at the end of lay when given cafeteria access to energy, protein, and calcium. Poultry Science 64, 1696-1712.

Chauve C 1998. The poultry red mite Dermanyssus gallinae: current situation and future prospects for control. Veterinary Parasitology 79, 239-245. 
Cunningham DL, Tienhoven AV and Gvaryahu G 1988. Population size, cage area, and dominance rank effects on productivity and well-being of laying hens. Poultry science 63, 399-406.

Grobas S, Mendez J, De Blas C and Mateos GG 1999. Laying hen productivity as affected by energy, supplemental fat, and linoleic acid concentration of the diet. Poultry Science 78, 1542-1551.

Gunawardana P, Roland DA and Bryant MM 2009. Effect of dietary energy, protein, and a versatile enzyme on hen performance, egg solids, egg composition, and egg quality of Hy-Line W-36 hens during second cycle, phase two. Journal of Applied Poultry Research 18, 43-53.

Keshavarz K 1998. Investigation on the possibility of reducing protein, phosphorus, and calcium requirements of laying hens by manipulation of time of access to these nutrients. Poultry Science 77, 1320-1332.

Lesna I, Wolfs P, Faraji F, Roy L, Komdeur J and Sabelis MW 2009. Candidate predators for biological control of the poultry red mite Dermanyssus gallinae. Experimental and Applied Acarology 48, 63-80.

Mongin P and Sauveur B 1974. Voluntary food and calcium intake by the laying hen. British Poultry Science 15, 349-359.

Nahashon SN, Adefope N, Amenyenu A and Wright D 2005. Effect of dietary metabolisable energy and crude protein concentrations on growth performance and carcass characteristics of French guinea fowl broilers. Poultry Science Journal 84, 337-344.

Nir I, Melcion JP and Picard M 1990. Effect of particle-size of sorghum grains on feed-intake and performance of young broilers. Poultry Science 69, 2177-2184

Penz AM and Jensen LS 1991. Influence of protein-concentration, amino-acid supplementation, and daily time of access to high-protein or low-protein diets on egg weight and components in laying hens. Poultry Science 70, 2460-2466.

Perez-Bonilla A, Novoa S, Garcia J, Mohiti-Asli M, Frikha M and Mateos GG 2012. Effects of energy concentration of the diet on productive performance and egg quality of brown egg-laying hens differing in initial body weight. Poultry Science 91, 3156-3166.
Plavnik I, Wax E, Sklan D, Bartov I and Hurwitz S 1997. The response of broiler chickens and turkey poults to dietary energy supplied either by fat or carbohydrates. British Poultry Science 76, 1000-1005

Rutter K, Hennoste L, Ward LC, Cornish BH and Thomas BJ 1998. Bioelectrical impedance analysis for the estimation of body composition in rats. Laboratory Animals 32, 65-71.

Safaa HM, Jimenez-Moreno E, Valencia DG, Frikha M, Serrano MP and Mateos GG 2009. Effect of main cereal of the diet and particle size of the cereal on productive performance and egg quality of brown egg-laying hens in early phase of production. Poultry Science 88, 608-614.

Sauvant D, Perez J-M and Tran G 2004. Tables of composition and nutritional value of feed materials. INRA Editions and AFZ. Wageningen Academic Publishers, Paris, France.

Short FJ, Gorton P, Wiseman J and Boorman KN 1996. Determination of titanium dioxide added as an inert marker in chicken digestibility studies. Animal Feed Science and Technology 59, 215-221.

Summers JD and Lesson S 1985. Commercial poultry nutrition, 3rd edition. Nottingham University Press Editions, University of Guelph, Ontarion, Canada.

Traineau M, Bouvarel I, Mulsant C, Roffidal L, Launay C and Lescoat P 2013. Effects on performance of ground wheat with or without insoluble fiber or whole wheat in sequential feeding for laying hens. Poultry Science 92, 2475-2486. Umar Faruk M, Bouvarel I, Meme N, Rideau N, Roffidal L, Tukur HM, Bastianelli D, Nys $Y$ and Lescoat $P$ 2010. Sequential feeding using whole wheat and a separate protein-mineral concentrate improved feed efficiency in laying hens. Poultry Science 89, 785-796.

Umar Faruk M, Bouvarel I, Mallet S, Ali MN, Tukur HM, Nys $\mathrm{Y}$ and Lescoat $\mathrm{P}$ 2011. Is sequential feeding of whole wheat more efficient than ground wheat in laying hens? Animal 5, 230-238.

Valkonen $E$, Venalainen $E$, Rossow $L$ and Valaja J 2008. Effects of dietary energy content on the performance of laying hens in furnished and conventional cages. Poultry Science 87, 844-852. 